\title{
Efeito da temperatura e do fotoperíodo no desenvolvimento micelial de Sclerotium cepivorum, agente causal da podridão branca do alho e da cebola
}

\author{
Leandro Luiz Marcuzzo ${ }^{1}$, Andrey Xavier ${ }^{1}$
}

\begin{abstract}
${ }^{1}$ Instituto Federal Catarinense - IFC/Campus Rio do Sul, CP 441, 89.163-356, Rio do Sul, SC
Autor para correspondência: Leandro Luiz Marcuzzo (marcuzzo@ifc-riodosul.edu.br)

Data de chegada: 11/08/2016. Aceito para publicação em: 28/01/2017.
\end{abstract}

$10.1590 / 0100-5405 / 167785$

A podridão branca, causada por Sclerotium cepivorum Berk. é uma das mais importantes doenças de solo do alho (Allium sativum L.) e da cebola (Allium cepa L.). A doença é conhecida há muito tempo em algumas áreas produtoras no sul e sudeste do Brasil, causando grandes perdas em lavouras instaladas em locais altamente infestados pelo patógeno e sob condições ambientais favoráveis (Reis \& Oliveira, Identificação e manejo da podridão-branca do alho e da cebola. Brasília: Embrapa hortaliças, comunicado técnico 91, 6 p. 2013). Os sintomas da doença podem ser observados na parte aérea dessas culturas pelo subdesenvolvimento, amarelecimento e morte das folhas mais velhas e também da planta, bem como a podridão dos bulbos. As raízes também apodrecem de modo que as plantas sejam facilmente arrancadas do solo. Em ambiente úmido, os bulbos e a região do caule próximo ao solo ficam recobertos por abundante micélio branco onde são produzidas de forma aglomerada estruturas de resistência conhecidas como escleródios. A morte de plantas pode ocorrer em reboleiras ou em grandes áreas dependendo do grau de infestação e após a colheita, os bulbos doentes podem mumificar ou apodrecer. Pesquisas relacionadas à podridão branca no Brasil ainda são escassas. Para tanto, o conhecimento da biologia do patógeno é de grande importância para compreender o desenvolvimento da doença no campo e, consequentemente, prescrever medidas eficientes para o seu controle. Diante disso, este trabalho teve como objetivo avaliar em condições in vitro a influência da temperatura e do fotoperíodo no desenvolvimento micelial de $S$. cepivorum. O trabalho foi realizado no Laboratório de Microbiologia e Fitopatologia do Instituto Federal
Catarinense - IFC/Campus Rio do Sul, sendo o experimento conduzido em delineamento inteiramente casualizado com cinco repetições em cada tratamento. O inóculo de $S$. cepivorum foi obtido a partir de micélio e escleródios armazenado na geladeira $\left( \pm 4^{\circ} \mathrm{C}\right)$ em placas de Petri contendo meio de cultura BDA (Batata-Dextrose-Ágar). Discos de micélio com $9 \mathrm{~mm}$ de diâmetro foram removidos dessas placas e inoculados no centro de placas de Petri com $8 \mathrm{~cm}$ de diâmetro contendo meio de cultura BDA e incubados em câmera de germinação do tipo B.O.D. (Demanda Biológica de Oxigênio) a uma temperatura de $25^{\circ}$ $\mathrm{C}$ e fotoperíodo de 12 horas durante sete dias para crescimento do micélio e obtenção do inóculo. Após isso, discos de micélio desse crescimento foram transferidos para placas de Petri contendo meio de cultura BDA e incubados nas temperaturas de $5,10,15,20,25$, e $30^{\circ} \mathrm{C}$ $\left( \pm 1^{\circ} \mathrm{C}\right)$ e fotoperíodo de 12 horas. Diariamente era feito a avaliação do crescimento micelial do fungo com auxílio de um paquímetro nos diâmetros opostos de cada tratamento, até que um deles apresentasse crescimento em toda a superfície do meio nas placas de Petri. Isto ocorreu aos seis dias de incubação nas placas incubadas a temperatura de $20^{\circ} \mathrm{C}$. A partir da obtenção da temperatura ótima de desenvolvimento, repetiu-se o ensaio seguindo a mesma metodologia de inoculação, incubando-se a temperatura ideal com fotoperíodos variáveis de $0,6,12,18$ e 24 horas, a fim de avaliar o fotoperíodo favorável ao desenvolvimento micelial.Verificou-se que a temperatura influenciou no crescimento micelial, tendo apresentado melhor desenvolvimento entre as temperaturas de $15^{\circ} \mathrm{e} 20^{\circ} \mathrm{C}$ (Figura 1A). Utilizando a equação gerada pela curva $\left(y=-0,045 x^{2}+1,588 x-6,032, R^{2}=0,973\right)$ (Figura $\left.1 \mathrm{~A}\right)$,
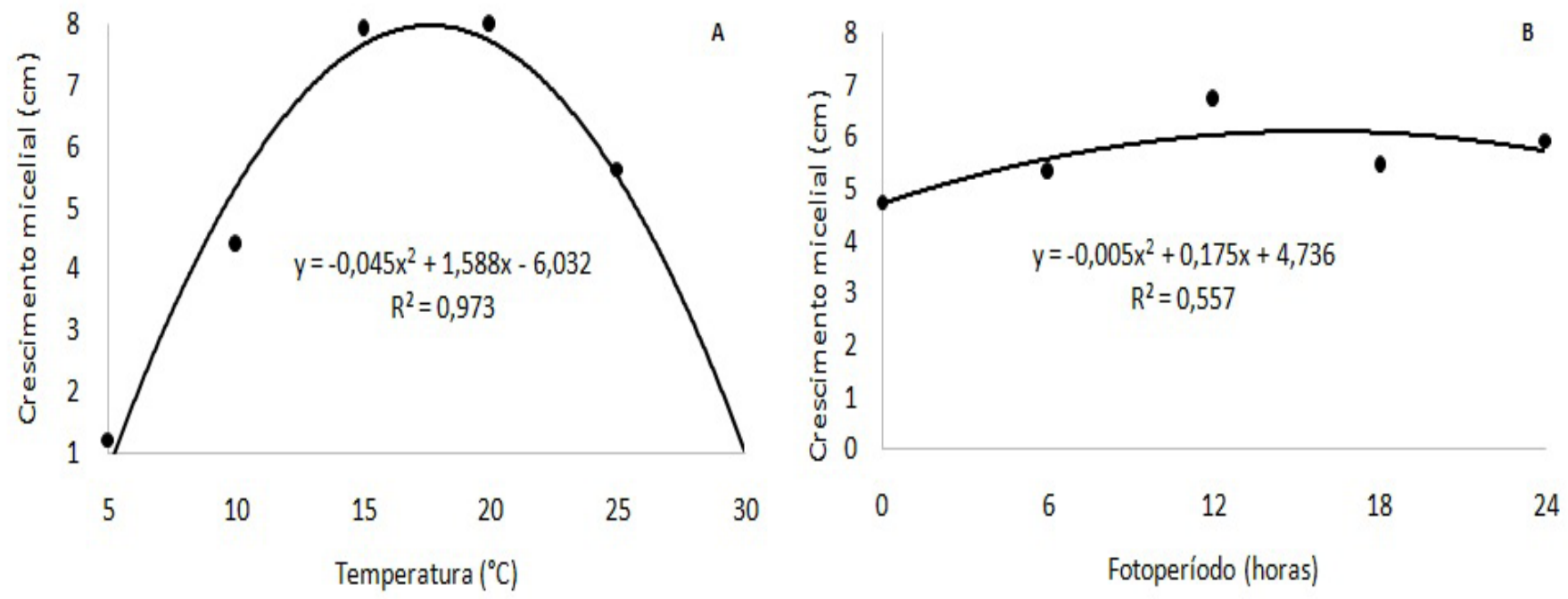

Figura 1. Curva de crescimento micelial (cm) in vitro de S. cepivorum em diferentes temperaturas (A) e fotoperíodos (B). IFC/Campus Rio do Sul, 2016. 
obtém-se a temperatura ideal de $18^{\circ} \mathrm{C}$ para o crescimento micelial de $S$. cepivorum. Leite et al. (Summa Phytopathologica, v.26, n.2, p.81-84, 2000) destacaram que a temperatura ótima para o desenvolvimento do micélio de Sclerotinia sclerotiorum situa-se na faixa próxima aos $18^{\circ} \mathrm{C}$, reforçando a tese que temperaturas mais baixas são ideais para o desenvolvimento de fungos que produzem escleródio. Temperaturas extremas não são favoráveis ao desenvolvimento micelial do fungo, pois a $30^{\circ} \mathrm{C}$ observou-se (Figura $1 \mathrm{~A}$ ) a inibição do crescimento micelial, enquanto que a $5^{\circ} \mathrm{C}$ quase não houve desenvolvimento da colônia $(1,24$ $\mathrm{cm})$. Em relação ao crescimento micelial em diferentes fotoperíodos, observa-se a formação de uma linha polinomial (Figura 1B) e através da equação $y=-0,0056 x^{2}+0,1756 x+4,7366\left(R^{2}=0,5578\right)$ verificou-se que o fotoperíodo mais favoravel ao desenvolvimento é de 12 horas de luz com um crescimento micelial de $6,71 \mathrm{~cm}$ quando comparado a zero horas de luz que obteve um crescimento de $4,75 \mathrm{~cm}$. Mediante a isso, S. cepivorum tem seu desenvolvimento favorecido por dias nublados e temperaturas amenas. As informações obtidas em relação à temperatura e o fotoperíodo no crescimento micelial de $S$. cepivorum permitem um maior conhecimento da biologia do agente causal da podridão branca do alho e da cebola, auxiliando no entendimento da epidemiologia e suporte para manejo da doença no campo. 